\title{
PENILAIAN KESEHATAN BUMN YANG TERDAFTAR DI BURSA EFEK INDONESIA (BEI) DALAM MASA PANDEMI COVID-19
}

\author{
Rendy Mirwan Aspirandi \\ Universitas Muhammadiyah Jember \\ rendymirwanaspirandi@unmuhjember.ac.id \\ Seno Sumowo \\ Universitas Muhammadiyah Jember \\ senosumowo@unmuhjember.ac.id \\ Disubmit : 17 Juli 2021 \\ Direview : 2 November 2021 \\ Diterima : 24 November 2021
}

\begin{abstract}
Based on the news circulating that Indonesia's economic growth until the third quarter of 2020 contracted $-2.03 \%$. This contraction caused Indonesia to be included in the list of countries declared a recession. Thus, BUMN revenues are seen as still low, even the Minister of Finance is targeting the revenue of Separated State Assets (KND) in 2021 to decrease by $40 \%$ compared to the end of 2020 (https://nasional.kontan.co.id/). KND is a state asset that comes from the income of BUMN. The decrease in the target in 2021 shows that many BUMN will experience a decrease in income in 2020 to 2021. This decline in income may vary for each BUMN. The main problem that occurs is the decline in BUMN income will trigger a decrease in the health level of BUMN.

The result of the analysis shows that BUMN predicate as HEALTHY with the highest total score is SMGR with a score of 91. On the other hand, BUMN with a LESS HEALTH predicate with the lowest total score is JSMR with a value of 42.6. These results give a signal to investors that SOEs with HEALTHY conditions will be more able to survive amid business competition during the Covid-19 Pandemic, on the other hand, BUMN with fewer HEALTH conditions will have a greater risk of bankruptcy so the signal given is to avoid it.

The conclusion that can be drawn is that SOEs that are predicated as HEALTHY with the highest total score are SMGR. On the other hand, SOEs that are predicated as LESS HEALTHY with the lowest total score are JSMR. This research is still limited to two indicators on operational aspects, namely: improving the quality of human resources and Research \& Development. In addition, in the administrative aspect, four indicators are still limited, namely: annual calculation reports, draft RKAP, periodic reports and performance of PUKK. PUKK performance is the availability of employee cooperatives or pension fund providers. Further research can further explore operational and administrative aspects. This research is still limited to two indicators on operational aspects, namely: improving the quality of human resources and Research \& Development. In addition, in the administrative aspect, four indicators are still limited, namely: annual calculation reports, draft RKAP, periodic reports and performance of PUKK.
\end{abstract}

Keywords: BUMN Health; Signaling Theory; Covid-19

\section{Abstrak}

Berdasarkan berita yang beredar bahwa pertumbuhan perekonomian Indonesia sampai kuartal III tahun 2020 terkontraksi -2,03\%. Kontraksi ini menyebabkan Indonesia juga masuk 
dalam daftar negara yang dinyatakan resesi. Sehingga, Pendapatan BUMN dipandang masih rendah, bahkan Menteri Keuangan menargetkan penerimaan Kekayaan Negara Dipisahkan (KND) 2021 turun 40\% dibandingkan akhir tahun 2020 (https://nasional.kontan.co.id/). KND merupakan kekayaan negara yang berasal dari pendapatan BUMN. Penurunan target di tahun 2021 ini menunjukkan bahwa banyak BUMN yang mengalami penurunan pendapatan di tahun 2020 sampai 2021. Penurunan pendapatan ini dapat bervariasi masingmasing BUMN. Permasalahan utama yang terjadi adalah penurunan pendapatan BUMN ini akan memicu penurunan tingkat kesehatan BUMN.

Penelitian ini menggunakan teknik analisis deskriptif. Metode Deskriptif yaitu metode yang digunakan untuk mencari unsurunsur, ciri-ciri, sifat-sifat suatu fenomena. Analisis deskriptif akan menghasilkan karakteristik setiap instrumen penelitian yang mencerminkan faktorfaktor yang menjadi penilaian kesehatan perusahaan BUMN.

Hasil analisis menunjukkan bahwa BUMN yang berpredikat SEHAT dengan total SKOR tertinggi adalah SMGR dengan nilai 91. Sebaliknya BUMN yang berpredikat KURANG SEHAT dengan total SKOR terendah adalah JSMR dengan nilai 42,6. Hasil tersebut memberikan sinyal kepada para investor bahwa BUMN dengan kondisi SEHAT akan lebih dapat bertahan di tengah persaingan bisnis saat Pandemi Covid-19, sebaliknya BUMN dengan kondisi KURANG SEHAT akan lebih besar risiko kebangkrutannya sehingga sinyal yang diberikan adalah untuk menghindarinya.

Kesimpulan yang dapat ditarik adalah BUMN yang berpredikat SEHAT dengan total SKOR tertinggi adalah SMGR. Sebaliknya BUMN yang berpredikat KURANG SEHAT dengan total SKOR terendah adalah JSMR. Penelitian ini masih terbatas kepada dua indikator pada aspek operasional, yaitu: peningkatan kualitas SDM dan Penelitian \& Pengembangan. Selain itu, pada aspek administrasi masih terbatas empat indikator, yaitu: laporan perhitungan tahunan, rancangan RKAP, laporan periodik dan kinerja PUKK. Kinerja PUKK adalah tersedianya koperasi pegawai atau penyedia dana pensiun. Penelitian selanjutnya dapat lebih mengeksplorasi aspek operasional dan aspek administrasi. Penelitian ini masih terbatas kepada dua indikator pada aspek operasional, yaitu: peningkatan kualitas SDM dan Penelitian \& Pengembangan. Selain itu, pada aspek administrasi masih terbatas empat indikator, yaitu: laporan perhitungan tahunan, rancangan RKAP, laporan periodik dan kinerja PUKK.

Kata Kunci: Kesehatan BUMN; Signaling Theory; Covid-19

\section{PENDAHULUAN}

Semenjak awal tahun 2020 di Indonesia dan berbagai negara belahan dunia sedang ditimpa musibah berupa pandemi Covid-19 atau Corona. Virus Covid-19 banyak menelan korban jiwa di seluruh dunia. Tercatat sampai Tanggal 17 November 2020 kasus di Indonesia mencapai 471.000, 395.000 sembuh dan 15.296 meninggal dunia (https://money.kompas.com/, 2020). Salah satu cara menghambat meluasnya Covid-19, berbagai negara melaksanakan tindakan lockdown termasuk Indonesia beberapa bulan di awal tahun 2020. Namun, lockdown di Indonesia disebut dengan Pembatasan Sosial Berskala Besar (PSBB). Lockdown dan PSBB ini menghambat aktivitas perdagangan baik nasional maupun internasional. Akibat dari PSBB di Indonesia banyak perusahaan swasta dan BUMN yang mengalami penurunan pendapatan.

Berdasarkan berita yang beredar bahwa pertumbuhan perekonomian Indonesia sampai kuartal III tahun 2020 terkontraksi -2,03\%. Kontraksi ini menyebabkan Indonesia juga masuk dalam daftar negara yang dinyatakan resesi. Pertumbuhan perekonomian Indonesia yang negatif menandakan bahwa pendapatan seluruh perusahaan yang beroperasi di Indonesia mengalami penurunan. BUMN juga menjadi salah satu korban dari terjadinya pandemi Covid19. Banyak BUMN yang mengalami penurunan pendapatan selama tahun 2020 ini. Pendapatan 
BUMN masih rendah, bahkan Menteri Keuangan menargetkan penerimaan Kekayaan Negara Dipisahkan (KND) 2021 turun 40\% dibandingkan akhir tahun 2020 (https://nasional.kontan.co.id/). KND merupakan kekayaan negara yang berasal dari pendapatan BUMN. Penurunan target di tahun 2021 ini menunjukkan bahwa banyak BUMN yang mengalami penurunan pendapatan di tahun 2020 sampai 2021. Penurunan pendapatan ini dapat bervariasi masing-masing BUMN. Permasalahan utama yang terjadi adalah penurunan pendapatan BUMN ini akan memicu penurunan tingkat kesehatan BUMN. Tingkat kesehatan BUMN merupakan indikator yang sangat penting dalam menentukan tingkat eksistensi BUMN dalam persaingan di dunia usaha terutama bagi BUMN yang telah menjadi perusahaan terbuka (Nasution \& Sari, 2016).

Sebanyak 22 perusahaan BUMN yang telah menjadi perusahaan terbuka dan sahamnya diperdagangkan di Bursa Efek Indonesia (BEI) sangat penting dalam menilai tingkat kesehatan BUMN tersebut. Investor yang kebanyakan lebih percaya untuk berinvestasi di perusahaan BUMN khususnya perbankan harus mengetahui tingkat kesehatan BUMN perbankan tersebut (Kaligis, 2013). Hal ini dikarenakan guna menilai keberlanjutan kegiatan bisnis perusahaan dari saham yang investor miliki.

Investor islami memiliki kecenderungan melakukan analisis terhadap saham perusahaan sebelum melakukan investasi (Aspirandi et al., 2020). Analisis yang berkaitan dengan outcome akuntansi adalah menilai kesehatan BUMN yang berdasar pada Keputusan Menteri Badan Usaha Milik Negara Nomor: KEP-100/MBU/2002. Peraturan ini menjelaskan bahwa teknik menilai kesehatan BUMN didasarkan pada 3 unsur utama, yaitu: aspek keuangan, aspek operasional dan aspek administrasi. Ketiga aspek ini akan dianalisis yang selanjutnya menghasilkan bobot penilaian yang dikelompokkan pada setiap level-level kesehatan BUMN.

Analisis fundamental sangat diperlukan investor untuk menilai tingkat kesehatan perusahaan (Baresa, Suzana; Bogdan , Sinisa; Ivanovic, 2013). Banyak metode yang dapat digunakan untuk menilai saham yang bermasalah di pasar, dengan penggunaan salah satu teknik, seorang investor dapat mengetahui suatu fundamental saham bermasalah atau tidak (D'Amico, 2013). Penggunaan teknik yang tepat dalam menilai perusahaan akan menghasilkan forecasting yang akurat mengenai pertumbuhan kinerja perusahaan di masa depan (Lin \& Chen, 2007). Perusahaan asuransi BUMN di Pontianak memiliki tingkat kesehatan yang baik dengan tingkat kesehatan AA (Diana, 2016). Kesehatan BUMN PG. Djatiroto mengalami penurunan dari tahun 2012-2014 (Iswahyudi et al., 2016). BUMN PT Garuda Indonesia (Persero), Tbk. memiliki tingkat kesehatan yang fluktuatif dengan tingkat kesehatan pada tahun 2011 dan 2012 AA, menurun di tahun 2013 A, tahun 2014 BBB, dan tahun 2015 A (Wijayanti, 2016). PT. Waskita Karya (Persero), Tbk. menyandang predikat sehat selama tahun 2014-2015 (Nasution dan Sari, 2016). PT. Adhi Karya (Persero) dan Tbk., PT. Waskita Karya (Persero), Tbk. dalam keadaan yang tidak sehat, sedangkan PT. Pembangunan Perumahan (Persero), Tbk. dalam area abu-abu selama tahun 2017 (Dinarjito, 2018). PT. Adhi Karya (Persero), Tbk. memiliki predikat kesehatan BUMN yaitu A selama tahun 2012-2014 (Bahara, 2015). Penelitian terdahulu tersebut merupakan bukti di masa lalu sebelum pandemi covid-19. Namun, masih jarang sekali bahkan tidak ditemukan penelitian yang meneliti tingkat kesehatan BUMN pada saat Pandemi Covid-19. Oleh karena itu, penelitian ini dipandang perlu diteliti ulang.

Penelitian ini dinilai sangat penting karena dalam kondisi pandemi Covid-19 di tahun 2020 ini, banyak perusahaan khususnya BUMN yang aktivitas operasionalnya terganggu. Salah satu contohnya PT. Garuda Indonesia, tbk. yang merupakan perusahaan BUMN penerbangan terbesar di Indonesia yang telah melakukan Pemutusan Hubungan Kerja (PHK) sebanyak 700 karyawan (https://finance.detik.com, 2021). Berita tersebut menjadi sentimen negatif kepada para investor khususnya investor islami yang mendasarkan keputusan investasinya pada hasil analisis kinerja perusahaan. Terjadinya PHK disuatu perusahaan menjadi suatu tanda bahwa keuangan perusahaan sedang menghadapi situasi yang kurang baik. Secara jangka panjang, 
perusahaan yang memiliki kondisi keuangan yang tidak baik akan menuju pada jurang kebangkrutan. Oleh karena itu, penilaian kesehatan BUMN sangat penting dilakukan untuk mengetahui suatu BUMN betul-betul sudah tidak sehat atau masih tergolong sehat. Penelirian ini akan mengeksplorasi tentang Apakah 22 perusahaan BUMN yang terdaftar di Bursa Efek Indonesia memiliki tingkat kesehatan perusahaan yang baik berdasarkan Keputusan Menteri Badan Usaha Milik Negara Nomor: KEP-100/MBU/2002?

Signaling Theory adalah bahwa manajer dan pemegang saham tidak memiliki akses informasi perusahaan yang sama atau adanya asimetri informasi. Ada informasi tertentu yang hanya diketahui oleh manajer, sedangkan para pemegang saham tidak mengetahui informasi tersebut. Akibatnya, ketika kebijakan pendanaan perusahaan mengalami perubahan, hal itu dapat membawa informasi kepada pemegang saham yang akan menjadikan nilai perusahaan berubah. Dengan kata lain, muncul pertanda atau sinyal (Wongso, 2013). Sinyal tersebut menjadi dasar investor islami sebagai landasan mengambil keputusan investasi.

\section{METODE PENELITIAN}

Penilaian Tingkat Kesehatan BUMN berdasarkan Keputusan Menteri Badan Usaha Milik Negara Nomor: KEP-100/MBU/2002 berlaku bagi seluruh BUMN non jasa keuangan maupun BUMN jasa keuangan kecuali Persero Terbuka dan BUMN yang dibentuk dengan Undangundang tersendiri. BUMN non jasa keuangan adalah BUMN yang bergerak dibidang infrastruktur dan non infrastruktur. BUMN jasa keuangan adalah BUMN yang bergerak dalam bidang usaha perbankan, asuransi, jasa pembiayaan dan jasa penjaminan. Penilaian Tingkat Kesehatan BUMN digolongkan menjadi:

1) SEHAT, yang terdiri dari :

1.1) AAA apabila total (TS) lebih besar dari 95

1.2) AA apabila $80<\mathrm{TS}<=95$

1.3) A apabila $65<\mathrm{TS}<=80$

2) KURANG SEHAT, yang terdiri dari :

2.1) $\quad$ BBB apabila $50<\mathrm{TS}<=65$

2.2) $\quad$ BB apabila $40<\mathrm{TS}<=50$

2.3) $\quad$ B apabila $30<\mathrm{TS}<=40$

3) TIDAK SEHAT, yang terdiri dari :
3.1) $\quad$ CCC apabila $20<\mathrm{TS}<=30$
3.2) $\quad$ CC apabila $10<\mathrm{TS}<=20$
3.3) $\quad$ C apabila $\mathrm{TS}<=10$

Penilaian total bobot untuk aspek keuangan pada BUMN dibedakan menjadi 2, yaitu: BUMN Infra Struktur (Infra) memiliki total bobot 50 dan BUMN Non Infra Struktur (Non infra) memiliki total bobot 70 . Indikator-indikator yang akan dinilai sebagai berikut:

Tabel 1. Indikator Aspek Keuangan

\begin{tabular}{rlrr}
\hline \multirow{2}{*}{ No. } & \multicolumn{1}{c}{ Indikator } & \multicolumn{2}{c}{ Bobot } \\
\cline { 3 - 4 } & & Infra & Non Infra \\
\hline 1 & Imbalan kepada pemegang saham (ROE) & 15 & 20 \\
\hline 2 & Imbalan Investasi (ROI) & 10 & 15 \\
\hline 3 & Rasio Kas & 3 & 5 \\
\hline 4 & Rasio Lancar & 4 & 5 \\
\hline 5 & Collection Periods & 4 & 5 \\
\hline 6 & Perputaran Persediaan & 4 & 5 \\
\hline
\end{tabular}




\begin{tabular}{rlrr}
\hline 7 & Perputaran total asset & 4 & 5 \\
\hline 8 & Rasio modal sendiri terhadap total aktiva & 6 & 10 \\
\hline & Total Bobot & 50 & 70 \\
\hline
\end{tabular}

Sumber: Keputusan Menteri Badan Usaha Milik Negara Nomor: KEP-100/MBU/2002

Aspek operasional memiliki total bobot yang akan dibedakan menjadi 2, yaitu: Infrastruktur dan Non Infrastruktur. Penjelasan sebagai berikut:

- BUMN INFRASTRUKTUR 35

- BUMN NON INFRASTRUKTUR 15

Penilaian terhadap masing-masing indikator dilakukan secara kualitatif dengan kategori penilaian dan penetapan skornya sebagai berikut :

- Baik sekali (BS) : skor $=100 \%$ x Bobot indikator yang bersangkutan

- Baik (B) : skor $=80 \%$ x Bobot indikator yang bersangkutan

- Cukup (C) : skor $=50 \%$ x Bobot indikator yang bersangkutan

- Kurang (K) : skor $=20 \%$ x Bobot indikator yang bersangkutan

Tabel 2. Contoh Penilaian Aspek Operasional

\begin{tabular}{|c|c|c|c|c|c|}
\hline No. & $\begin{array}{c}\text { Indikator yang } \\
\text { digunakan }\end{array}$ & Bobot & Nilai & Skor & $\begin{array}{l}\text { Unsur-unsur yang } \\
\text { dipertimbangkan }\end{array}$ \\
\hline 1 & $\begin{array}{l}\text { Pelayanan } \\
\text { kepadapelanggan/ } \\
\text { masyarakat. }\end{array}$ & 15 & B & 12 & $\begin{array}{l}\text { Turn Round Time (TRT), } \\
\text { Waiting Time (WT), dsb. }\end{array}$ \\
\hline 2 & $\begin{array}{l}\text { Peningkatan kualitas } \\
\text { SDM }\end{array}$ & 10 & $\mathrm{C}$ & 5 & $\begin{array}{l}\text { Peningkatan Kesejahteraan, } \\
\text { Kaderisasi pimpinan, dsb. }\end{array}$ \\
\hline 3 & $\begin{array}{l}\text { Research \& } \\
\text { Development }\end{array}$ & 10 & $\mathrm{D}$ & 8 & $\begin{array}{l}\text { Kepedulian manajemen } \\
\text { terhadap R\&D, dsb. }\end{array}$ \\
\hline & Total & 35 & & 25 & \\
\hline
\end{tabular}

Sumber: Keputusan Menteri Badan Usaha Milik Negara Nomor: KEP-100/MBU/2002

Aspek administrasi memiliki total bobot yang akan dibedakan menjadi 2, yaitu: Infrastruktur dan Non Infrastruktur. Penjelasan sebagai berikut:

- BUMN INFRASTRUKTUR 15

- BUMN NON INFRASTRUKTUR 15

Tabel 3. Daftar Indikator dan Bobot Aspek Administrasi

\begin{tabular}{lcc}
\hline \multicolumn{1}{c}{ Bobot Indikator } & Infra & Non Infra \\
\hline 1. Laporan Perhitungan Tahunan & 3 & 3 \\
\hline 2. Rancangan RKAP & 3 & 3 \\
\hline 3. Laporan Periodik & 3 & 3 \\
\hline 4. Kinerja PUKK & 6 & 6 \\
\hline Total & 15 & 15 \\
\hline
\end{tabular}

Sumber: Keputusan Menteri Badan Usaha Milik Negara Nomor: KEP-100/MBU/2002

Penelitian ini menggunakan data sekunder. Data sekunder adalah data yang berasal dari data yang sudah tersedia. Data sekunder yang digunakan adalah bentuk data luantitatif dan kualitatif. Data telah tersedia di dalam laporan keuangan perusahaan yang terdaftar di Bursa Efek Indonesia pada situs http://idx.co.id. 
Populasi dan Sampel Populasi adalah gabungan dari seluruh elemen yang terbentuk peristiwa, hal, atau orang yang memiliki karakteristik serupa yang menjadi pusat perhatian peneliti, karena dipandang sebagai semesta penelitian. Populasi adalah wilayah generalisasi yang terdiri atas objek/subjek yang mempunyai kualitas dan karakteristik tertentu yang ditetapkan oleh peneliti untuk dipelajari dan kemudian ditarik kesimpulan. Sampel adalah bagian dari jumlah dan karakteristik yang dimiliki oleh populasi tersebut (Sugiyono, 2008).

Populasi dalam penelitian ini adalah seluruh perusahaan BUMN yang terdaftar di Bursa Efek Indonesia. Dikarenakan perusahaan BUMN yang terdaftar di Bursa Efek Indonesia hanya Berjumlah 22 BUMN, maka penelitian ini mengambil semua BUMN sebagai data penelitian.

Teknik pengumpulan data dalam penelitian ini adalah dengan menggunakan teknik dokumentasi. Data sekunder akan didapatkan dari laporan keuangan masing-masing perusahaan yang masuk dalam data penelitian yang di unduh melalui http://idx.co.id.

Penelitian ini menggunakan teknik analisis deskriptif. Metode Deskriptif yaitu metode yang digunakan untuk mencari unsurunsur, ciri-ciri, sifat-sifat suatu fenomena. Metode ini dimulai dengan mengumpulkan data, menganalisis data dan menginterprestasikannya (Suryana, 2010). Analisis deskriptif dilaksanakan dengan bantuan Microsoft Excel. Analisis deskriptif akan menghasilkan karakteristik setiap instrumen penelitian yang mencerminkan faktor-faktor yang menjadi penilaian kesehatan perusahaan BUMN. Instrumen tersebut adalah Aspek Keuangan, aspek operasional dan aspek administrasi. Hasil perhitungan akan lebih lanjut dianalisis secara mendalam dalam penentuan tingkat kesehatan perusahaan BUMN. Analisis bersifat deskriptif kuantitatif. Dimana hasil olah data kuantitatif dari Microsoft Excel akan dideskripsikan secara mendalam berdasarkan hasil yang telah didapatkan.

\section{HASIL DAN PEMBAHASAN}

Penelitian ini tidak menggunakan semua sampel penelitian. Beberapa sampel penelitian dikeluarkan dari analisis karena beberapa hal yang tidak dapat dipenuhi. Berikut tabel rincian sampel penelitian yang digunakan dalam analisis.

Tabel 4. Rincian Sampel Penelitian

\begin{tabular}{lllcl}
\hline No. & Kode & \multicolumn{1}{c}{ Nama Perusahaan } & Ceklist & \multicolumn{1}{c}{ Keterangan } \\
\hline 1 & INAF & $\begin{array}{l}\text { PT. Indofarma (Persero), } \\
\text { Tbk. }\end{array}$ & $\times$ & $\begin{array}{l}\text { Laporan keuangan } \\
\text { tidak terbit sampai } \\
\text { batas waktu penelitian }\end{array}$ \\
\hline 2 & KAEF & $\begin{array}{l}\text { PT. Kimia Farma (Persero), } \\
\text { Tbk. }\end{array}$ & $\sqrt{ }$ & \\
\hline 3 & PGAS & $\begin{array}{l}\text { PT. Perusahaan Gas Negara } \\
\text { (Persero), Tbk. }\end{array}$ & $\times$ & $\begin{array}{l}\text { Laporan keuangan } \\
\text { tidak terbit sampai } \\
\text { batas waktu penelitian }\end{array}$ \\
\hline 4 & KRAS & $\begin{array}{l}\text { PT. Krakatau Steel } \\
\text { (Persero), Tbk. }\end{array}$ & $\times$ & $\begin{array}{l}\text { Laporan keuangan } \\
\text { tidak terbit sampai } \\
\text { batas waktu penelitian }\end{array}$ \\
\hline 5 & ADHI & $\begin{array}{l}\text { PT. Adhi Karya (Persero), } \\
\text { Tbk. }\end{array}$ & $\sqrt{ }$ & \\
\hline 6 & PTPP & $\begin{array}{l}\text { PT. Pembangunan } \\
\text { Perumahan (Persero), Tbk. }\end{array}$ & $\sqrt{ }$ & \\
\hline 7 & WIKA & $\begin{array}{l}\text { PT. Wijaya Karya (Persero), } \\
\text { Tbk. }\end{array}$ & $\sqrt{ }$ & \\
\hline
\end{tabular}




\begin{tabular}{|c|c|c|c|c|}
\hline 8 & WSKT & $\begin{array}{l}\text { PT. Waskita Karya } \\
\text { (Persero), Tbk. }\end{array}$ & $\sqrt{ }$ & \\
\hline 9 & BBNI & $\begin{array}{l}\text { PT. Bank Negara Indonesia } \\
\text { (Persero), Tbk. }\end{array}$ & $x$ & $\begin{array}{l}\text { Perbankan dan } \\
\text { Lembaga Keuangan } \\
\text { tidak masuk dalam } \\
\text { analisis Keputusan } \\
\text { Menteri Badan Usaha } \\
\text { Milik Negara Nomor: } \\
\text { KEP-100/MBU/2002 }\end{array}$ \\
\hline 10 & BBRI & $\begin{array}{l}\text { PT. Bank Rakyat Indonesia } \\
\text { (Persero), Tbk. }\end{array}$ & $x$ & $\begin{array}{l}\text { Perbankan dan } \\
\text { Lembaga Keuangan } \\
\text { tidak masuk dalam } \\
\text { analisis Keputusan } \\
\text { Menteri Badan Usaha } \\
\text { Milik Negara Nomor: } \\
\text { KEP-100/MBU/2002 }\end{array}$ \\
\hline 11 & BBTN & $\begin{array}{l}\text { PT. Bank Tabungan Negara } \\
\text { (Persero), Tbk. }\end{array}$ & $x$ & $\begin{array}{l}\text { Perbankan dan } \\
\text { Lembaga Keuangan } \\
\text { tidak masuk dalam } \\
\text { analisis Keputusan } \\
\text { Menteri Badan Usaha } \\
\text { Milik Negara Nomor: } \\
\text { KEP-100/MBU/2002 }\end{array}$ \\
\hline 12 & BMRI & $\begin{array}{l}\text { PT. Bank Mandiri (Persero), } \\
\text { Tbk. }\end{array}$ & $x$ & $\begin{array}{l}\text { Perbankan dan } \\
\text { Lembaga Keuangan } \\
\text { tidak masuk dalam } \\
\text { analisis Keputusan } \\
\text { Menteri Badan Usaha } \\
\text { Milik Negara Nomor: } \\
\text { KEP-100/MBU/2002 }\end{array}$ \\
\hline 13 & ANTM & $\begin{array}{l}\text { PT. Aneka Tambang } \\
\text { (Persero), Tbk. }\end{array}$ & $\sqrt{ }$ & \\
\hline 14 & PTBA & $\begin{array}{l}\text { PT. Bukit Asam (Persero), } \\
\text { Tbk. }\end{array}$ & $\sqrt{ }$ & \\
\hline 15 & TINS & PT. Timah (Persero), Tbk. & $\sqrt{ }$ & \\
\hline 16 & SMBR & $\begin{array}{l}\text { PT. Semen Baturaja } \\
\text { (Persero), Tbk. }\end{array}$ & $\sqrt{ }$ & \\
\hline 17 & SMGR & $\begin{array}{l}\text { PT. Semen Indonesia } \\
\text { (Persero), Tbk. }\end{array}$ & $\sqrt{ }$ & \\
\hline 18 & JSMR & $\begin{array}{l}\text { PT. Jasa Marga (Persero), } \\
\text { Tbk. }\end{array}$ & $\sqrt{ }$ & \\
\hline 19 & GIAA & $\begin{array}{l}\text { PT. Garuda Indonesia } \\
\text { (Persero), Tbk. }\end{array}$ & $x$ & $\begin{array}{l}\text { Laporan keuangan } \\
\text { tidak terbit sampai } \\
\text { batas waktu penelitian }\end{array}$ \\
\hline 20 & TLKM & $\begin{array}{l}\text { PT. Telekomunikasi } \\
\text { Indonesia (Persero), Tbk. }\end{array}$ & $x$ & $\begin{array}{l}\text { Laporan keuangan } \\
\text { tidak terbit sampai } \\
\text { batas waktu penelitian }\end{array}$ \\
\hline 21 & AGRO & $\begin{array}{l}\text { PT. Bank BRI Agro } \\
\text { (Persero), Tbk. }\end{array}$ & $x$ & $\begin{array}{l}\text { Perbankan dan } \\
\text { Lembaga Keuangan }\end{array}$ \\
\hline
\end{tabular}




\begin{tabular}{lll}
\hline & & tidak masuk dalam \\
& & analisis Keputusan \\
& & Menteri Badan Usaha \\
& & Milik Negara Nomor: \\
& & KEP-100/MBU/2002 \\
\hline $22 \quad$ WTON & $\begin{array}{l}\text { PT. Wijaya Karya Beton } \\
\text { (Persero), Tbk. }\end{array}$ & \\
\hline Total Jumlah Sampel & $\sqrt{ }$ \\
\hline
\end{tabular}

Sumber: Data diolah

Sampel yang digunakan adalah sampel yang bertanda centang $(\sqrt{ })$. Selain tanda centang tidak digunakan dalam sampel penelitian.

Pada bagian aspek keuangan terdapat beberapa indikator keuangan yang dinilai, yaitu: Imbalan kepada pemegang saham (ROE), Imbalan Investasi (ROI), Rasio Kas, 
Aspirandi \& Sumowo: Penilaian Kesehatan BUMN ...

Rasio Lancar, Collection Periods, Perputaran Persediaan, Perputaran total asset, dan Rasio modal sendiri terhadap total aktiva. Berikut akan disajikan tabel penilaian tingkat kesehatan 12 BUMN dalam aspek keuangan.

Tabel 5. Kesehatan BUMN dalam Aspek Keuangan

\begin{tabular}{|c|c|c|c|c|c|c|c|c|c|c|c|c|c|c|c|c|c|}
\hline $\begin{array}{l}\text { Kode } \\
\text { UMN }\end{array}$ & ROE & SKOR & ROI & SKOR & $\begin{array}{l}\text { Cash } \\
\text { Rasio }\end{array}$ & SKOR & $\begin{array}{c}\text { Current } \\
\text { Ratio }\end{array}$ & SKOR & $\begin{array}{l}\text { Collection } \\
\text { Period }\end{array}$ & SKOR & $\begin{array}{l}\text { Perputaran } \\
\text { Persediaan }\end{array}$ & SKOR & TATO & SKOR & $\begin{array}{c}\text { TMS } \\
\text { Terhadap } \\
\text { TA }\end{array}$ & SKOR & $\begin{array}{l}\text { TOTA } \\
\text { SKOI }\end{array}$ \\
\hline$\overline{\mathrm{TBA}}$ & 14,22 & 18 & 65,23 & 15 & 119,88 & 5 & 216,00 & 5 & 33,26 & 5 & 16,97 & 5 & 212,50 & 5 & 70,41 & 7,5 & 65 \\
\hline MGR & 7,50 & 7,5 & 21,09 & 10 & 35,06 & 3 & 135,27 & 3 & 59,95 & 4 & 47,20 & 4 & 227,35 & 4 & 45,71 & 5,5 & \\
\hline INS & $-6,89$ & 0 & 7,67 & 6 & 21,20 & 3 & 111,80 & 4 & 28,73 & 5 & 69,12 & 4,5 & 233,98 & 5 & 34,03 & 10 & 37 \\
\hline TON & 3,63 & 5,5 & 6,54 & 5 & 32,77 & 4 & 111,51 & 4 & 48,08 & 5 & 60,32 & 4,5 & 94,02 & 4 & 39,85 & 10 & \\
\hline $\mathrm{AEF}$ & 0,29 & 2 & 3,35 & 4 & 18,42 & 3 & 89,78 & 0 & 55,69 & 5 & 89,58 & 4,5 & 169,91 & 5 & 40,46 & 9 & 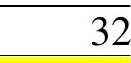 \\
\hline $\mathrm{DHI}$ & 0,43 & 1,5 & 0,39 & 2 & 15,28 & 2 & 111,16 & 2,5 & 100,68 & 3 & 213,08 & 1,2 & 36,51 & 1 & 14,63 & 1 & 1 \\
\hline TPP & 1,90 & 3 & 0,82 & 2 & 28,63 & 2,5 & 121,22 & 2,5 & 120,13 & 2,5 & 219,61 & 1,2 & 49,08 & 1,5 & 26,19 & 4 & 19 \\
\hline IKA & 1,94 & 3 & 0,36 & 2 & 33,85 & 2,5 & 108,63 & 2 & 48,02 & 4 & 216,60 & 1,2 & 41,84 & 1,5 & 24,46 & 4 & 20 \\
\hline & - & & - & & & & & & & & & & & & & & \\
\hline SKT & 57,28 & 1 & 31,69 & 0 & 3,02 & 0 & 67,45 & 0 & 99,74 & 3 & 94,89 & 3 & 53,81 & 1,5 & 15,70 & 3 & 11 \\
\hline NTM & 6,04 & 8,5 & 29,03 & 15 & 52,75 & 5 & 121,15 & 4 & 17,92 & 5 & 35,02 & 5 & 302,51 & 5 & 60,01 & 8 & 55 \\
\hline MBR & 0,32 & 1,5 & 18,32 & 10 & 46,14 & 3 & 133,03 & 3 & 95,44 & 3 & 52,96 & 4 & 157,58 & 4 & 59,40 & 5 & \\
\hline MR & $-0,17$ & 1 & 18,08 & 10 & 36,31 & 3 & 71,71 & 0 & 184,02 & 1,6 & 5,74 & 4 & 133,11 & 4 & 23,80 & 4 & 27 \\
\hline
\end{tabular}

Pada Tabel 5 yang bertanda kuning merupakan BUMN dalam sektor Infrastruktur dan tidak bertanda kuning merupakan BUMN Non Infrastruktur. Berdasarkan Keputusan Menteri Badan Usaha Milik Negara Nomor: KEP-100/MBU/2002 membedakan SKOR aspek keuangan antara BUMN Infrastruktur dan Non Infrastruktur. Penelitian ini mengelompokkan BUMN sektor Infrastruktur sebanyak 7 BUMN, yaitu: BUMN dengan kode saham SMGR, ADHI, PTPP, WIKA, WSKT, SMBR dan JSMR. Penelitian ini juga mengelompokkan BUMN sektor Non Infrastruktur sebanyak 5 BUMN, yaitu: BUMN dengan kode saham PTBA, TINS, WTON, KAEF dan ANTM.

Imbalan kepada pemegang saham (ROE) BUMN sektor Infrastruktur yang terbesar adalah SMGR bernilai 7,50 dengan SKOR 7,5. ROE BUMN sektor Infrastruktur yang terkecil adalah WSKT bernilai -57,28 dengan SKOR 1. ROE sektor Non Infrastruktur yang terbesar adalah PTBA bernilai 14,22 dengan SKOR 18. ROE BUMN sektor Non Infrastruktur terkecil adalah TINS bernilai -6,89 dengan SKOR 0. 
Imbalan Investasi (ROI) BUMN sektor Infrastruktur yang terbesar adalah SMGR bernilai 21,09 dengan SKOR 10. ROI BUMN sektor Infrastruktur yang terkecil adalah WSKT bernilai -31,69 dengan SKOR 0. ROI sektor Non Infrastruktur yang terbesar adalah PTBA bernilai 65,23 dengan SKOR 15. ROI BUMN sektor Non Infrastruktur terkecil adalah KAEF bernilai 3,35 dengan SKOR 4.

Rasio Kas (Cash Ratio) BUMN sektor Infrastruktur yang terbesar adalah SMBR bernilai 46,14 dengan SKOR 3. Cash Ratio BUMN sektor Infrastruktur yang terkecil adalah WSKT bernilai 3,02 dengan SKOR 0. Cash Ratio BUMN sektor Non Infrastruktur yang terbesar adalah PTBA bernilai 119,88 dengan SKOR 5. Cash Ratio BUMN sektor Non Infrastruktur terkecil adalah KAEF bernilai 18,42 dengan SKOR 3.

Rasio Lancar (Current Ratio) BUMN sektor Infrastruktur yang terbesar adalah SMGR bernilai 135,27 dengan SKOR 3. Current Ratio BUMN sektor Infrastruktur yang terkecil adalah WSKT bernilai 67,45 dengan SKOR 0. Current Ratio BUMN sektor Non Infrastruktur yang terbesar adalah PTBA bernilai 216,00 dengan SKOR 5. Current Ratio BUMN sektor Non Infrastruktur terkecil adalah KAEF bernilai 89,78 dengan SKOR 0.

Collection Periods BUMN sektor Infrastruktur yang terbaik adalah WIKA bernilai 48,02 dengan SKOR 4. Collection Periods BUMN sektor Infrastruktur yang terburuk adalah JSMR bernilai 184,02 dengan SKOR 1,6. Collection Periods BUMN sektor Non Infrastruktur yang terbaik adalah ANTM bernilai 17,92 dengan SKOR 5. Collection Periods BUMN sektor Non Infrastruktur terburuk adalah KAEF bernilai 55,69 dengan SKOR 5.

Perputaran Persediaan BUMN sektor Infrastruktur yang terbaik adalah JSMR bernilai 5,74 dengan SKOR 4. Perputaran Persediaan BUMN sektor Infrastruktur yang terburuk adalah PTPP bernilai 219,61 dengan SKOR 1,2. Perputaran Persediaan BUMN sektor Non Infrastruktur yang terbaik adalah PTBA bernilai 16,97 dengan SKOR 5. Perputaran Persediaan BUMN sektor Non Infrastruktur terburuk adalah KAEF bernilai 89,58 dengan SKOR 4,5.

Perputaran total asset (TATO) BUMN sektor Infrastruktur yang terbaik adalah SMGR bernilai 227,35 dengan SKOR 4. TATO BUMN sektor Infrastruktur yang terburuk adalah ADHI bernilai 36,51 dengan SKOR 1. TATO BUMN sektor Non Infrastruktur yang terbaik adalah ANTM bernilai 302,51 dengan SKOR 5. TATO BUMN sektor Non Infrastruktur terburuk adalah WTON bernilai 94,02 dengan SKOR 4.

Rasio modal sendiri terhadap total aktiva (TMS Terhadap TA) BUMN sektor Infrastruktur yang terbaik adalah SMGR bernilai 45,71 dengan SKOR 5,5. TMS Terhadap TA BUMN sektor Infrastruktur yang terburuk adalah ADHI bernilai 14,63 dengan SKOR 1. TMS Terhadap TA BUMN sektor Non Infrastruktur yang terbaik adalah WTON bernilai 39,85 dengan SKOR 10. TMS Terhadap TA BUMN sektor Non Infrastruktur terburuk adalah PTBA bernilai 70,41 dengan SKOR 7,5.

Total SKOR aspek keuangan terbesar dari BUMN sektor infrastruktur adalah SMGR bernilai 41, tetapi total SKOR aspek keuangan terkecil dari BUMN sektor infrastruktur adalah WSKT bernilai 11. Total SKOR aspek keuangan terbesar dari BUMN sektor non infrastruktur adalah PTBA bernilai 65,5, tetapi total SKOR aspek keuangan terkecil dari BUMN sektor non infrastruktur adalah KAEF bernilai 32,5.

Pada hasil total SKOR aspek keuangan telah diketahui bahwa perusahaan BUMN yang memiliki aspek keuangan yang paling sehat adalah SMGR dari sektor infrastruktur dan PTBA dari sektor non infrastruktur. "Kesehatan aspek keuangan sangat penting untuk diperhatikan, karena dengan keadaan keuangan yang sehat maka perusahaan khususnya BUMN akan dapat lebih bertahan di industrinya." (Lin \& Chen, 2007). Titik awal untuk mengetahui sebuah perusahaan sehat atau tidak adalah melalui analisis keadaan keuangan perusahaan, yaitu: melalui Laporan Keuangan Tahunan yang telah diterbitkan oleh perusahaan. Pendemi Covid- 
19 membuat keadaan keuangan perusahaan semakin tertekan. Tertekannya keadaan keuangan ini dikarenakan diberlakukannya lockdown diberbagai negara secara global. Kebijakan lockdown ini yang menghambat proses bisnis perusahaan. Proses bisnis perushaan terhambat karena terganggunya kegiatan ekspor dan impor yang dapat dilakukan oleh perusahaan. Perusahaan dituntut untuk dapat mempertahankan kesehatan keuangannya oleh para investor. Keadaan keuangan yang mulai menurun akan menjadi sinyal (Teori Sinyal) bagi para investor untuk mengevaluasi lebih dalam keadaan perusahaannya.

"Peran seorang CFO (Chief Financial Offircer) sangat berpengaruh dalam mempertahankan tingkat kesehatan perusahaan khususnya perusahaan BUMN." (Bahara, 2015). CFO harus dapat menerima semua informasi yang ada di dalam perusahaan mulai dari proses produks sampai pemasaran. Tugas terberat CFO adalah menjaga aliran kas dan balance sheet tetap positif. CFO mengolah semua informasi yang didapatkan, selanjutnya mengolahnya dan mengambil keputusan untuk melakukan efektifitas, efisiensi dan ekonomisasi dalam proses bisnis internal perusahaan. Ketiga kata kunci tersebut harus diterapkan pada saat masa pandemi covid-19 ini untuk mempertahankan tingkat kesehatan perusahaan khususnya BUMN.

Pada bagian aspek operasional terdapat dua indikator utama yang dinilai, yaitu: peningkatan kualitas Sumber Daya Manusia (SDM) dan Penelitian \& Pengembangan (Research \& Development). Aspek operasional membedakan total SKOR antara perusahaan BUMN sektor infrastruktur dan non infrastruktur. Perusahaan BUMN infrastruktur memiliki SKOR maksimal peningkatan kualitas SDM bernilai 15 dan Research \& Development bernilai 20 dengan total SKOR bernilai 35. Perusahaan BUMN non infrastruktur memiliki SKOR maksimal peningkatan kualitas SDM bernilai 8 dan Research \& Development bernilai 7 dengan total SKOR bernilai 15. Berikut akan disajikan tabel penilaian tingkat kesehatan 12 BUMN dalam aspek operasional:

Tabel 6. Kesehatan BUMN dalam Aspek Operasional

\begin{tabular}{lrrrr}
\hline Kode BUMN & Peningkatan Kualitas SDM & Research \& Development & SKOR \\
\hline PTBA & 8 & 1,4 & 9,4 \\
\hline SMGR & 15 & 20 & 35 \\
\hline TINS & 8 & 0 & 8 \\
\hline WTON & 4 & 7 & 11 \\
\hline KAEF & 0 & 7 & 7 \\
\hline ADHI & 15 & 0 & 15 \\
\hline PTPP & 0 & 20 & 20 \\
\hline WIKA & 0 & 20 & 20 \\
\hline WSKT & 0 & 20 & 20 \\
\hline ANTM & 8 & 7 & 15 \\
\hline SMBR & 15 & 20 & 35 \\
\hline JSMR & 0 & 0 & 0 \\
\hline
\end{tabular}

Sumber: Data diolah

Pada Tabel 6 yang bertanda kuning merupakan BUMN dalam sektor Infrastruktur dan tidak bertanda kuning merupakan BUMN Non Infrastruktur. Penelitian ini mengelompokkan BUMN sektor Infrastruktur sebanyak 7 BUMN, yaitu: BUMN dengan kode saham SMGR, ADHI, PTPP, WIKA, WSKT, SMBR dan JSMR. Penelitian ini juga mengelompokkan BUMN sektor Non Infrastruktur sebanyak 5 BUMN, yaitu: BUMN dengan kode saham PTBA, TINS, WTON, KAEF dan ANTM. 
Peningkatan Kualitas SDM BUMN sektor infrastruktur yang tetap dilaksanakan adalah SMGR, ADHI dan SMBR. BUMN sektor infrastruktur yang tidak melaksanakan peningkatan SDM adalah PTPP, WIKA, WSKT dan JSMR. Peningkatan Kualitas SDM BUMN sektor non infrastruktur yang tetap dilaksanakan adalah PTBA, TINS, WTON dan ANTM. BUMN sektor non infrastruktur yang tidak melaksanakan peningkatan SDM adalah KAEF.

Research \& Development BUMN sektor infrastruktur yang tetap dilaksanakan adalah SMGR, PTPP, WIKA, WSKT dan SMBR. BUMN sektor infrastruktur yang tidak melaksanakan Research \& Development adalah ADHI dan JSMR. Research \& Development BUMN sektor non infrastruktur yang tetap dilaksanakan adalah PTBA, WTON, KAEF dan ANTM. BUMN sektor infrastruktur yang tidak melaksanakan Research \& Development adalah TINS.

Pada hasil total SKOR aspek operasional telah diketahui bahwa perusahaan BUMN yang memiliki aspek operasional yang paling sehat adalah SMGR dan SMBR dari sektor infrastruktur dan ANTM dari sektor non infrastruktur. BUMN dengan kode saham SMGR, SMBR dan ANTM tetap melaksanakan kegiatan operasional berupa Peningkatan Kualitas SDM dan Research \& Development secara maksimal meskipun dalam kondisi Pandemi Covid19. "Dua indikator aspek operasional ini dapat mempertahankan keberlanjutan kualitas manajemen perusahaan di masa depan." (Baresa, Suzana; Bogdan , Sinisa; Ivanovic, 2013). Kegiatan peningkatan kualitas SDM dibutuhkan oleh perusahaan guna mempertahankan kualitas kinerja karyawan perusahaan di masa depan. Sedangkan, Research \& Development dibutuhkan oleh perusahaan untuk menciptakan sebuah inovasi-inovasi terhadap produk dan jasa perusahaan.

Pada Tabel 6 terdapat 2 perusahaan BUMN yang patut menjadi sorotan adalah PTBA dan WTON. Keduanya merupakan perusahaan BUMN sektor non infrastruktur. PTBA tetap melaksanakan kegiatan Research \& Development tetapi melakukan suatu efisiensi yang terlihat dari SKOR bernilai 1,4 dengan SKOR maksimal 7. Selain itu, WTON tetap melaksanakan kegiatan peningkatan kualitas SDM tetapi juga melakukan tindakan efisiensi yang terlihat dari SKOR bernilai 4 dengan SKOR maksimal 8. Tindak efisiensi ini dilakukan untuk mengurangi beban keuangan tetapi tetap menjaga tingkat kesehatan aspek operasional. Fenomena ini memberikan sinyal positif (Teori Sinyal) bahwa perusahaan secara agresif melakukan efisiensi operasional tetapi tetap menjaga tingkat kesehatan aspek operasional ditengah tekanan bisnis dalam masa Pandemi Covid-19.

Pada bagian aspek administrasi terdapat empat indikator utama yang dinilai, yaitu: laporan perhitungan tahunan, rancangan RKAP, laporan periodik dan kinerja PUKK. Aspek administrasi tidak membedakan total SKOR antara perusahaan BUMN sektor infrastruktur dan non infrastruktur. Indikator laporan perhitungan tahunan memiliki SKOR maksimal 3, rancangan RKAP memiliki SKOR maksimal 3, laporan periodik memiliki SKOR maksimal 3 dan kinerja PUKK memiliki SKOR maksimal 6. Oleh karena itu, total SKOR aspek administrasi bernilai 15 .

Tabel 7. Kesehatan BUMN dalam Aspek Administrasi

\begin{tabular}{lrrrrr}
\hline $\begin{array}{c}\text { Kode } \\
\text { BUMN }\end{array}$ & $\begin{array}{c}\text { Laporan } \\
\text { Perhitungan } \\
\text { Tahunan }\end{array}$ & $\begin{array}{c}\text { Rancangan } \\
\text { RKAP }\end{array}$ & $\begin{array}{c}\text { Laporan } \\
\text { Periodik }\end{array}$ & $\begin{array}{c}\text { Kinerja } \\
\text { PUKK }\end{array}$ & SKOR \\
\hline PTBA & 3 & 3 & 3 & 0 & 9 \\
\hline SMGR & 3 & 3 & 3 & 6 & 15 \\
\hline TINS & 3 & 3 & 3 & 0 & 9 \\
\hline
\end{tabular}


Aspirandi \& Sumowo: Penilaian Kesehatan BUMN ...

\begin{tabular}{lllllr}
\hline WTON & 3 & 3 & 3 & 6 & 15 \\
\hline KAEF & 3 & 3 & 3 & 6 & 15 \\
\hline ADHI & 3 & 3 & 3 & 6 & 15 \\
\hline PTPP & 3 & 3 & 3 & 6 & 15 \\
\hline WIKA & 3 & 3 & 3 & 6 & 15 \\
\hline WSKT & 3 & 3 & 3 & 6 & 15 \\
\hline ANTM & 3 & 3 & 3 & 0 & 9 \\
\hline SMBR & 3 & 3 & 3 & 0 & 9 \\
\hline JSMR & 3 & 3 & 3 & 6 & 15 \\
\hline SUmber
\end{tabular}

Sumber: Data diolah

Pada Tabel 7 yang bertanda kuning merupakan BUMN dalam sektor Infrastruktur dan tidak bertanda kuning merupakan BUMN Non Infrastruktur. Penelitian ini mengelompokkan BUMN sektor Infrastruktur sebanyak 7 BUMN, yaitu: BUMN dengan kode saham SMGR, ADHI, PTPP, WIKA, WSKT, SMBR dan JSMR. Penelitian ini juga mengelompokkan BUMN sektor Non Infrastruktur sebanyak 5 BUMN, yaitu: BUMN dengan kode saham PTBA, TINS, WTON, KAEF dan ANTM.

Perusahaan BUMN baik sektor infrastruktur maupun non infrastruktur semua telah memenuhi kewajiban administrasi secara tepat waktu dalam hal laporan perhitungan tahunan, rancangan RKAP, dan laporan periodik. Pada indikator kinerja PUKK yang memilikinya adalah SMGR, WTON, KAEF, ADHI, PTPP, WIKA, WSKT dan JSMR. Perusahaan BUMN yang tidak memiliki kinerja PUKK adalah PTBA, TINS, ANTM dan SMBR. Kinerja PUKK adalah suatu kegiatan yang dilakukan oleh perusahaan dalam hal pembinaan UMKM (Usaha Mikro, Kecil dan Menengah) dan koperasi.

Pemenuhan aspek administrasi memberikan sinyal positif (Teori Sinyal) bahwa perusahaan masih memperhatikan ketepatan dalam pemenuhan kewajiban administrasinya. "Investor akan menilai lebih apabila perusahaan memenuhi kewajiban administrasinya secara tepat waktu." (Dinarjito, 2018). Investor akan lebih mempercayai kinerja manajemen perusahaan yang memenuhi kewajiban pelaporan keuangan (administrasi) secara tepat waktu. Hal ini menandakan bahwa perusahaan telah melaksanakan Good Corporate Governance (GCG) yang baik.

Pada bagian ini akan dibahas mengenai tingkat kesehatan BUMN. Berikut akan disajikan tabel yang memuat informasi mengenai tingkat kesehatan BUMN.

Tabel 8. Tingkat Kesehatan BUMN

\begin{tabular}{|c|c|c|c|c|c|c|}
\hline $\begin{array}{l}\text { KODE } \\
\text { BUMN }\end{array}$ & $\begin{array}{c}\text { ASPEK } \\
\text { KEUANGAN }\end{array}$ & $\begin{array}{c}\text { ASPEK } \\
\text { OPERASIONAL }\end{array}$ & $\begin{array}{c}\text { ASPEK } \\
\text { ADMINISTRASI }\end{array}$ & $\begin{array}{l}\text { TOTAL } \\
\text { SKOR }\end{array}$ & KONDISI & PREDIKAT \\
\hline PTBA & 65,5 & 9,4 & 9 & 83,9 & SEHAT & $\mathrm{AA}$ \\
\hline SMGR & 41 & 35 & 15 & 91 & SEHAT & $\mathrm{AA}$ \\
\hline TINS & 37,5 & 8 & 9 & 54,5 & $\begin{array}{l}\text { KURANG } \\
\text { SEHAT }\end{array}$ & $\mathrm{BBB}$ \\
\hline WTON & 42 & 11 & 15 & 68 & SEHAT & A \\
\hline KAEF & 32,5 & 7 & 15 & 54,5 & $\begin{array}{l}\text { KURANG } \\
\text { SEHAT }\end{array}$ & BBB \\
\hline ADHI & 14,2 & 15 & 15 & 44,2 & $\begin{array}{l}\text { KURANG } \\
\text { SEHAT }\end{array}$ & $\mathrm{BB}$ \\
\hline
\end{tabular}




\begin{tabular}{|c|c|c|c|c|c|c|}
\hline & & & \multicolumn{4}{|c|}{ KURANG } \\
\hline РТPP & 19,2 & 20 & 15 & 54,2 & SEHAT & BBB \\
\hline WIKA & 20,2 & 20 & 15 & 55,2 & $\begin{array}{l}\text { KURANG } \\
\text { SEHAT }\end{array}$ & $\mathrm{BBB}$ \\
\hline WSKT & 11,5 & 20 & 15 & 46,5 & $\begin{array}{l}\text { KURANG } \\
\text { SEHAT }\end{array}$ & $\mathrm{BB}$ \\
\hline ANTM & 55,5 & 15 & 9 & 79,5 & SEHAT & A \\
\hline SMBR & 33,5 & 35 & 9 & 77,5 & SEHAT & A \\
\hline JSMR & 27,6 & 0 & 15 & 42,6 & $\begin{array}{l}\text { KURANG } \\
\text { SEHAT }\end{array}$ & $\mathrm{BB}$ \\
\hline
\end{tabular}

Sumber: Data diolah

Pada Tabel 8 diketahui bahwa BUMN yang memiliki kondisi SEHAT dengan Predikat AA adalah PTBA dan SMGR. BUMN yang memiliki kondisi SEHAT dengan Predikat A adalah WTON, ANTM dan SMBR. BUMN yang memiliki kondisi KURANG SEHAT dengan Predikat BBB adalah TINS, KAEF, PTPP dan WIKA. BUMN yang memiliki kondisi KURANG SEHAT dengan Predikat BB adalah ADHI, WSKT dan JSMR.

Apabila dilihat dari total SKOR yang paling besar adalah SMGR dengan nilai 91. Sebaliknya, total SKOR yang paling kecil adalah JSMR dengan nilai 42,6. KONDISI dan PREDIKAT yang ditampilkan pada Tabel 5.5 memberikan sinyal (Teori Sinyal) kepada investor dalam hal pengambilan keputusan investasi. "Kondisi perusahaan yang sehat memberikan sinyal positif kepada para investor untuk berinvestasi di sebuah perusahaan, sebaliknya apabila kondisi perusahaan kurang sehat memberikan sinyal negatif kepada para investor untuk lebih mempertimbangkan keputusan berinvestasi di perusahaan yang bersangkutan." (D’Amico, 2013). Pada dasarnya setiap investor dalam mengambil keputusan investasinya memiliki sebuah landasan terlebih dahulu. Salah satu landasan yang digunakan oleh para investor adalah perhitungan tingkat kondisi kesehatan BUMN berdasarkan Keputusan Menteri Badan Usaha Milik Negara Nomor: KEP-100/MBU/2002.

Sesuai dengan Teori Sinyal bahwa skor paling besar SMGR menghasilkan sinyal yang positif bagi investor islami untuk berimvestasi pada saham perusahaan SMGR. Sebaliknya Skor paling kecil dihasilkan JSMR yang menghasilkan sinyal negatif untuk dihindari untuk berinvestasi di saham JSMR.

Investor akan lebih tertarik berinvestasi pada perusahaan dalam kondisi sehat. Kondisi perusahaan yang sehat memberikan sebuah jaminan dana yang dimiliki oleh investor akan memberikan tingkat pengembalian (return) yang tinggi. Selain tingkat pengembalian investasi, investor juga membutuhkan suatu jaminan keamanan terhadap dana yang ditempatkan dalam sebuah saham perusahaan. Jaminan keamanan yang diberikan oleh perusahaan dengan kondisi sehat adalah rendahnya tingkat risiko kebangkrutan dari perusahaan yang bersangkutan. Sebaliknya, tingkat risiko kebangkrutan sebuah perusahaan akan tinggi apabila kondisi perusahaannya kurang sehat atau bahkan tidak sehat. Oleh karena itu, para investor secara langsung akan menghindari untuk berinvestasi pada perusahaan-perusahaan yang memiliki kondisi yang kurang sehat atau tidak sehat.

\section{SIMPULAN}

Pada Tahun 2020 ini merupakan tahun yang berat bagi Badan Usaha Milik Negara (BUMN) dalam persaingan bisnis. Beban berat yang ditanggung ini karena sejak awal tahun 2020 telah terjadinya Pandemi Covid-19 di Indonesia. Berdasarkan berita yang beredar bahwa pertumbuhan perekonomian Indonesia sampai kuartal III tahun 2020 terkontraksi -2,03\%. 
Pertumbuhan perekonomian yang negatif ini diakibatkan oleh siklus bisnis yang mulai melambat karena dibeberapa negara termasuk Indonesia melakukan sistem lockdown untuk menurunkan risiko penyebaran Virus Covid-19. Perlambatan bisnis ini juga menimpa BUMN di Indonesia. Tindakan yang sangat penting dilakukan oleh investor saat ini sebelum berinvestasi khususnya di perusahaan BUMN adalah menilai tingkat kesehatan BUMN dengan menggunakan aspek dan indikator dalam Keputusan Menteri Badan Usaha Milik Negara Nomor: KEP-100/MBU/2002.

Teori Sinyal menyatakan bahwa segala informasi yang berada di pasar merupakan sinyal bagi para pengguna informasi. Apabila dikaitkan dengan kondisi kesehatan BUMN, maka hasil dari analisis mengenai kondisi kesehtaan BUMN berdasarkan Keputusan Menteri Badan Usaha Milik Negara Nomor: KEP-100/MBU/2002 merupakan sinyal bagi para investor dalam mengambil keputusan berinvestasi.

Hasil analisis menunjukkan bahwa BUMN yang berpredikat SEHAT dengan total SKOR tertinggi adalah SMGR dengan nilai 91. Sebaliknya BUMN yang berpredikat KURANG SEHAT dengan total SKOR terendah adalah JSMR dengan nilai 42,6. Hasil tersebut memberikan sinyal kepada para investor bahwa BUMN dengan kondisi SEHAT akan lebih dapat bertahan di tengah persaingan bisnis saat Pandemi Covid-19, sebaliknya BUMN dengan kondisi KURANG SEHAT akan lebih besar risiko kebangkrutannya sehingga sinyal yang diberikan adalah untuk menghindarinya.

Kontribusi secara teori adalah penelitian ini menunjukkan hasil bahwa skor kesehatan SMGR yang tinggi menghasilkan sinyal yang baik bagi investor islami utnutk berinvestasi pada saham SMGR. Sebaliknya kondisi kesehatan JSMR yang rendah menghasilkan sinyal yang negatif untuk dihindari oleh investor islami.

Kontribusi praktis adalah hasil penelitian ini memberikan wawasan kepada investor islami dalam menilai kesehatan BUMN. Salah satu cara yang dapat dilakukan adalam berdasarkan rumus pada Keputusan Menteri Badan Usaha Milik Negara Nomor: KEP100/MBU/2002.

Penelitian ini masih terbatas kepada dua indikator pada aspek operasional, yaitu: peningkatan kualitas SDM dan Penelitian \& Pengembangan. Selain itu, pada aspek administrasi masih terbatas empat indikator, yaitu: laporan perhitungan tahunan, rancangan RKAP, laporan periodik dan kinerja PUKK.

Penelitian selanjutnya dapat lebih mengeksplorasi aspek operasional dan aspek administrasi. Penelitian ini masih terbatas kepada dua indikator pada aspek operasional, yaitu: peningkatan kualitas SDM dan Penelitian \& Pengembangan. Selain itu, pada aspek administrasi masih terbatas empat indikator, yaitu: laporan perhitungan tahunan, rancangan RKAP, laporan periodik dan kinerja PUKK.

\section{DAFTAR PUSTAKA}

Aspirandi, R. M., Setianingsih, W. E., Ramadhana, R., \& Maftahah, R. (2020). Peran Accounting Information Bagi Investor Islami. Jati: Jurnal Akuntansi Terapan Indonesia, 3(2), 80-93. https://doi.org/10.18196/jati.030229

Bahara, W. (2015). ANALISIS TINGKAT KESEHATAN PERUSAHAAN DARI ASPEK KEUANGAN BERDASARKAN SURAT KEPUTUSAN MENTERI BUMN NOMOR: KEP-100/MBU/2002 (Studi Kasus pada PT ADHI KARYA (Persero) Tbk. Periode 20122014). Jurnal Administrasi Bisnis S1 Universitas Brawijaya, 26(1), 86221.

Baresa, Suzana; Bogdan , Sinisa; Ivanovic, Z. (2013). www.econstor.eu. 4(1), 45-51.

D'Amico, G. (2013). A semi-Markov approach to the stock valuation problem. Annals of Finance, 9(4), 589-610. https://doi.org/10.1007/s10436-012-0206-1

Diana, A. (2016). ANALISIS TINGKAT KESEHATAN PERUSAHAAN DALAM MENILAI 
KINERJA KEUANGAN PERUSAHAAN BUMN. 6, 15-25.

Dinarjito, A. (2018). Menilai Kesehatan BUMN Konstruksi yang Terdaftar di Bursa Efek Indonesia Sebagai Akibat Meningkatnya Proyek Infrastruktur Pemerintah. Substansi, 2(1), $1-18$.

Iswahyudi, D., Dwiatmanto, D., \& Azizah, D. (2016). ANALISIS TINGKAT KESEHATAN PERUSAHAAN BERDASARKAN KEPUTUSAN MENTERI BUMN NOMOR: KEP100/MBU/2002 (Studi Kasus pada Pabrik Gula Djatiroto Lumajang Periode 2012-2014). Jurnal Administrasi Bisnis S1 Universitas Brawijaya, 33(1), 98-104.

Kaligis, Y. (2013). Analisis Tingkat Kesehatan Bank Dengan Menggunakan Metode Camel Pada Industri Perbankan Bumn Yang Terdaftar Di Bursa Efek Indonesia. Jurnal Riset Ekonomi, Manajemen, Bisnis Dan Akuntansi, 1(3), 263-272. https://doi.org/10.35794/emba.v1i3.2015

Lin, P. C., \& Chen, J. S. (2007). FuzzyTree crossover for multi-valued stock valuation. Information Sciences, 177(5), 1193-1203. https://doi.org/10.1016/j.ins.2006.08.017

Nasution, L. K., \& Sari, S. N. (2016). Penilaian Tingkat Kesehatan Bumn Pada PT. WASKITA KARYA (PERSERO) Tbk. Jurnal BIS-A: Jurnal Administrasi, 05(01), 60-68. https://ejurnal.plm.ac.id/index.php/BIS-A/article/view/184

Sugiyono. (2008). Metode penelitian pendidikan : (pendekatan kuantitatif, kualitatif dan $R$ \& D).

Wongso, A. (2013). Pengaruh Kebijakan Dividen, Struktur Kepemilikan, dan Kebijakan Hutang terhadap Nilai Perusahaan dalam Perspektif Teori Agensi dan Teori Agensi dan Teori Signaling. Jurnal Ilmiah Mahasiswa Manajemen, Vol.1(No.5), 1-6.

https://finance.detik.com. (2021). Garuda Indonesia Putus Kontrak 700 Karyawan! https://finance.detik.com/berita-ekonomi-bisnis/d-5230271/garuda-indonesia-putuskontrak-700-karyawan

https://money.kompas.com/. (2020). Indonesia Resmi Resesi, Ekonomi Kuartal III-2020 Minus 3,49 Persen Halaman all - Kompas.com. https://money.kompas.com/read/2020/11/05/111828826/indonesia-resmi-resesiekonomi-kuartal-iii-2020-minus-349-persen?page $=$ all 